Это незначительно увеличивает среднее время восстановления, но существенно влияет на достижение требуемого значения комплексного показателя надежности изделия - его коэффициента готовности.

Впервые рассматривается возможность отношения радиоэлектронных систем к классу "абсолютно надежных" за счет особенностей метрологического и диагностического обеспечения. Исследовано влияние управляемых переменных на значение коэффициента готовности изделия. В зависимости от условий функиионирования ремонтного органа обоснованы допустимые требования к квалификации специалистов (среднее время выполнения проверки и устранения неисправности), а также к метрологической надежности средств измерительной техники.

По результатам исследований предложен алгоритм обеспечения требуемых значений показателей надежности изделий как во время их проектирования, так и при эксплуатации и восстановлении работоспособности в полевых условиях. Показано, что наибольшее влияние на значения показателей надежности изделий оказывает подготовка специилистов ремонтного органа, их умение в полном объеме использовать возможности современньх средств измерительной техники.

В статье рассмотрена возможность использования методов диагностирования цифровых радиоэлектронных систем и приведена оценка влияния качества диагностического обеспечения на надежность систем в иелом.

Ключевые слова: радиоэлектронные системы, диагностическое обеспечение, надежность.

\title{
ASSESSMENT OF THE INFLUENCE OF DIAGNOSTIC SUPPORT ON RELIABILITY OF RADIO ELECTRONIC SYSTEMS
}

Ye.V. Ryzhov, L.N. Sakovych, S.I. Glukhov, Yu.A. Nastishin

Currently, there is a trend of digital information processing in electronic weapons systems and military equipment. Software-controlled means of communication are being implemented. This requires new approaches in diagnosing them during maintenance, which are significantly different from the process of finding defects in analog tools.

Particular attention is paid to the introduction of modern advances in technical diagnostics and metrology. The possibility of using special methods for assessing the technical condition of digital devices (energy-static, energy-dynamic, electromagnetic), both separately and in combination. This slightly increases the average recovery time, but significantly affects the achievement of the required value of a comprehensive indicator of product reliability - its readiness factor.

For the first time, the possibility of classifying electronic systems as "absolutely reliable" due to the peculiarities of metrological and diagnostic software is considered. The influence of controlled variables on the value of the product readiness factor is investigated. Depending on the operating conditions of the repair body, the permissible values for the qualification of specialists (average time of inspection and troubleshooting), as well as for the metrological reliability of measuring equipment are justified.

According to the results of research, an algorithm for providing the necessary values of reliability indicators of products, both during their design and during operation and recovery in military conditions. It is shown that the greatest influence on the value of the reliability of products has the training of specialists of the repair body, their ability to fully use the capabilities of modern measuring equipment.

The article considers the possibility of using methods for diagnosing digital electronic systems and provides an assessment of the quality of diagnostic software for the reliability of systems as a whole.

Keywords: electronic systems, diagnostic support, reliability.

UDC 623.465 .35

DOI: https://doi.org/10.33577/2312-4458.24.2021.8-12

\section{B. Seredyuk}

Hetman Petro Sahaidachnyi National Army Academy, Lviv

\section{ANALYSIS OF MAGNETIC PROPERTIES OF $\mathrm{A}_{3} \mathrm{~B}_{6}$ TYPE OF SEMICONDUCTOR CRYSTALS WITH METALIC IMPURITIES DUE TO THEIR MILITARY APPLICATIONS}

The Earth's magnetic field is affected by the presence of heavy military armored vehicles which creates an additional magnetic moment. This distortion of the magnetic field, can be detected using magnetoresistive structures. This article touches base on the possibility of using semiconductor material such as InSe for high precision measurement of the magnetic field. The properties of InSe structures with regard to electrical, magnetic and optical characteristics are discussed. The effect of sharp anisotropy of InSe layered structure which consists in the strong covalent bond within the layers and a weak van-der-Waals bond in the interlayer space is discussed with regard to the explanation of how electrical, magnetic and optical properties are altered. The peculiarity of the spatial orientation of the material with regard to the direction of the magnetic field is considered. The impact of intercalation of InSe, GaSe by various concentrations of metal impurities such as nickel and other elements of 
$3 d$ iron group is studied. Bode diagrams for pure InSe system are compared with the ones of $N i_{x} I n S e$ (for various $x$ values). Also the effect of different temperatures ranging from room temperature to liquid nitrogen on the pattern of Bode diagrams is analyzed. The extent of how the magnetic properties of semiconductor crystals of the $A_{3} B_{6}$ type are altered by the presence of the metal impurities and their concentration is analyzed. Theoretic background for this paper is based on a well-known statement that layer structures such InSe or other $A_{3} B_{6}$ structures can be viewed as quasi two-dimensional. So, layers with strong covalent bond are formed by In-Se atoms, whereas interlayer space is filled with a weak Van der Waals bond. Within this model the processes across the layers can be described as a perturbation to the ones along the layers. This causes a strong anisotropy of the properties of these structures. Military implication of InSe structures mentioned throughout this paper is that these structures possess magnetoresistive properties and they were proved to be useful for the components of the magnetic sensors of civil and military use. This paper also touches base on how the InSe semiconductor crystals intercalated by 3d-elements can extend the functionality of magnetic sensors designed for heavy armor detection.

Keywords: semiconductor, intercalation, magnetic field, nanostructures.

\section{Introduction}

It is well known that the magnetic field by its nature is static and quite difficult to shield from. Earth owing to the rotation around its axis creates a magnetic field ranging from 20 up to 60 microTesla on its surface. Armored military vehicles consisting of a massive bulk of ferromagnetic material are subjected to the Earth's magnetic field. On the atomic level this massive armored bulk creates its own magnetic moment which interacts with the Earth's one. This causes some minor but still detectable distortion of the magnetic field. Magnetoresistive structures are supposed to be able to detect these distortions.

\section{Analysis of recent research and publications}

Nowadays plenty of technical systems that include modern anti-tank missiles contain sensitive magnetic sensors, where they help to pinpoint to the center of the target area and detect the region of a minimal armor. Moreover structures based on magnetoresistive systems are well resistant to temperature changes as well as ionizing radiation. That leads to their possible implications in guidance systems of modern warheads [1].

Magnetoresistive structures owing to their properties can not only provide a Coulomb blockade of the electric current but also create conditions for the emergence of new unique magnetic properties that may help to set the basis for new approaches to the development of information carriers technology. For instance, the giant magnetoresistive effect in semicondector nanostructures of the alternating nonmetal and metal layers may lead to the prospect of a further development of materials technology with regard to the creation of new types of information carriers as well as the creation of highly effective quantum computers.

\section{Basic statements}

The anomalies (perturbations) of the terrestrial magnetic field of the Earth are well detectable by the magnetic sensors, whereas modern digital analog signals processing methods allow a relatively precise determination of the mass, direction and velocity of the studied massive ferromagnetic objects [2]. Over the past few decades magnetoresistive structures proved their effectiveness and boosted their share on weaponary sensor technology sector.

The fact that magnetoresistive structures are objects that possess the ability to alter their currentvoltage plot when placed into an external magnetic field gives them possible implications in a wide range of areas including a military one. Detectors based on magneto-resistive structures are quite sensitive to the magnetic field perturbations (fluctuations) on the precision level of 10-15T at liquid helium temperatures, and less accurate - 10-13T at room temperature) [3]. This property of magneto-resistance is employed in a wide range of military systems, such as: navigation technology, submarine detection, target missile guidance and more.

The first prototypes of magnetic field sensors were developed around half of the century ago. These systems could detect a change in electrical resistance by $10 \%$ under small perturbations of the background magnetic field. Taking into account that already at that time the electrical resistance could be measured with a high precision, military vehicles which incorporated electronic components based on these structures showed their effectivness and were employed by the armed forces of several countries.

A giant magneto resistive effect was discovered in 1988 and proved that electrical resistance in a thin film of a non-magnetic material $(\mathrm{Cr})$, placed between two layers of ferromagnetic substance $(\mathrm{Fe})$ under the presence of a magnetic field is twice less than without field [4]. 
A quantum-mechanical theoretical approach gives some explanation for this phenomenon. According to this theory the spins of the conduction electrons of the magnetic material are aligned in the same direction under the presence of the magnetic field. The magnetization of the adjacent ferromagnetic layers of A3B6 structure is mostly opposite when no external magnetic field is applied. This is due to a weak antiferromagnetic interaction. The magnetic moments of the two adjacent A3B6 layers under the magnetic field are aligned in the same direction leading to a decrease of the conduction electrons scattering in the crystal lattice sites.

\section{The purpose of the article}

To investigate how a giant magnetoresistance effect affects the semiconductor based magnetic sensors, such as InSe, GaSe with the impurities of chromium, copper and germanium. To evaluate under what temperatures the structures of InSe, GaSe crystals experience their maximum sensitivity to the Earth's magnetic field perturbations. To analyze the impact of metalic impurity (namely nickel), its temperature and concentration on the electrical and magnetic properties of layered semiconductor crystals such as InSe.

\section{Presenting main material}

The studied layered semiconductor NixInSe crystal is not an ideal resistor because of the alternating diamagnetic ( $\mathrm{InSe}$ ) and ferromagnetic (Ni) nanolayers creating a distributed capacitance. Therefore, a standard method for determining the current-voltage plot for alternating current is used to study these structures [4]. InSe structure is described by the fact that it can be described using a quasi two-dimensional approach. According to this approach the layer within itself has a strong covalent bond created by In-Se atoms, while in the interlayer space an average distance between In-Se atoms is too large for a strong bond so a weak Van-derWaals bond is dominant in the direction perpendicular to the layers. This leads to strong anisotropic properties of these structures.

Introduction (intercalation) of different foreign ions, molecules or atoms, in particular metallic atoms of the iron $3 \mathrm{~d}$ transition group into the interlayer gap of the layered A3B6 material helps to create a wide range of new compounds with the unstudied properties. The presence of even a small concentration of metal impurities in the InSe matrix may significantly alter the electrical, magnetic and optical properties of the crystal. The magnetic moment of the introduced guest atoms will in its turn be affected by the lattice of the host crystal, which may lead to anomalous magnetic and kinetic properties of such structures [5].
So, the introduction of the element of $3 \mathrm{~d}$-iron group in the $\mathrm{TiSe} 2$ structure leads to the formation of Ti-M-Ti covalent centers. For the case of MxTiSe2, (where $\mathrm{M}-$ metal atoms of $\mathrm{Co}, \mathrm{Ni}, \mathrm{Ag}$ ) intercalation is accompanied by a decrease of the lattice constant along the axis of anisotropy [6].

The coupled atoms of of In-M-In in the NixInSe system can act not only as traps for ions and free electrons, but also as centers of crystalline lattice distortion. The introduction of $3 \mathrm{~d}$ group metal atoms into the structure of the layered semiconductor crystals may significantly affect their properties. That's why magnetization can be considered to be an important factor regulating electronic properties of InSe structure in the external magnetic field [5-6]. The influence of metal atoms of 3d-iron group on the matrix of InSe, GaSe was studied in detail in [7]. Some peculiarities of the behavior of In $4 \mathrm{Se} 3$ intercalated by metallic impurities have been discussed in $[8,9,10]$. Impedance spectroscopy measurements in the range of $10-3 \div 106$ $\mathrm{Hz}$ were carried out using an "AUTOLAB" measuring complex.

The frequency response of InSe and NixInSe structures can be determined by a well-known method of Bode diagram of total impedance and Bode phase diagram. Hence, to investigate the effect of metallic impurities on InSe structure Bode diagrams for: InSe; and $\mathrm{InSe}$ with $\mathrm{Ni}(3 \%)$ are outlined in the Figures below.
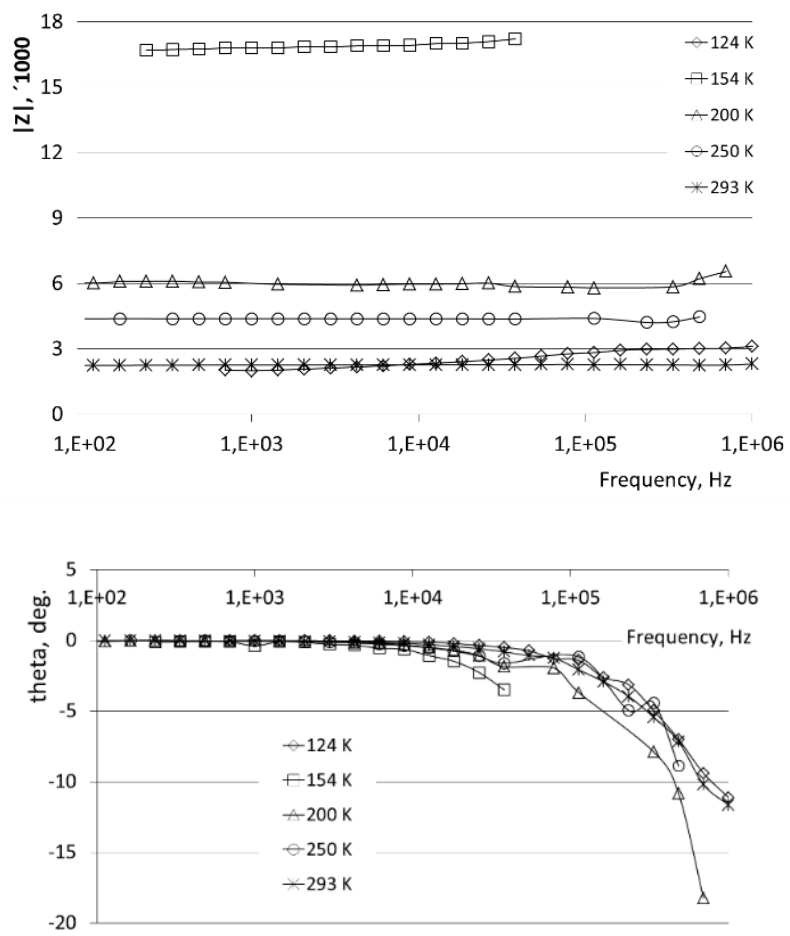

Fig. 1. Bode diagrams for pure InSe at different temperatures 

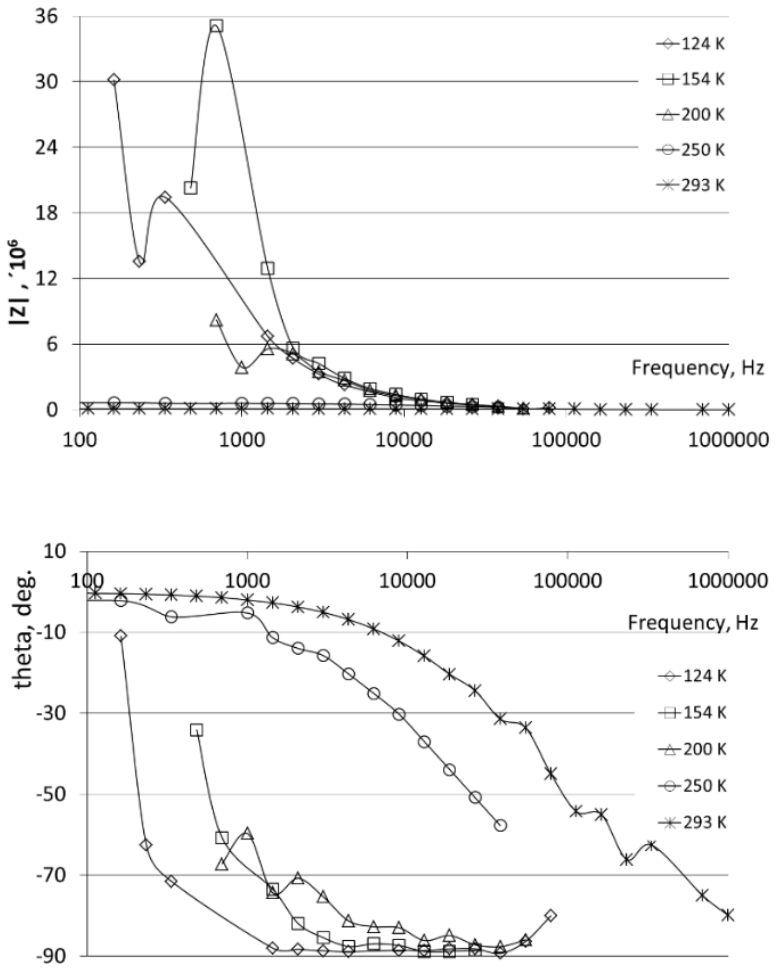

\section{Fig. 2. Bode diagrams for InSe with Ni (3\%) at different temperatures}

\section{Conclusions}

As it can be clearly seen from Figures 1 and 2 the presence of $\mathrm{Ni}$ makes considerable changes to total impedance and dielectric loss angle of InSe structure. This may be caused by the presence of the trap centers for charge carriers introduced by the guest $\mathrm{Ni}$ which makes ReZ and ImZ highly dependent on the frequency change. Temperature is proved to affect the slope and curvature of $\mathrm{Ni}_{\mathrm{x}} \mathrm{InSe}$ the Bode diagrams. This is in sharp contrast to the ones of pure InSe where Bode diagrams are not so highly dependent on temperature.

Structures with the alternating layers of semiconductor and metal due to their structural anisotropy provide a practical possibility to control and monitor the magnetic properties of the outside environment where these strutures are placed into. Moreover, these structures possess a sharp anisotropy of magnetic susceptibility. So, if such a sensor is fixed on the static axis and set for rotation with some frequency (likewise radar station) then this system may used for surveillance purposes and allow tracking of heavy armoured vehicles. The investigated semiconductor layer structures with the impurities of $3 d$ group metals can significantly extend the functionality of modern military magnetic sensors used for reconnaissance purposes.

\section{References}

1. Dalichaouch Y., Czipott, P. and Perry A. (2001), Magnetic sensors for battlefield applications. Proc. SPIE. Vol. 4393. pp. 129-134. DOI: https://doi.org/10.1117/12.441262.

2. Lenz J. and Edelstein A.S. (2006), Magnetic Sensors and Their applications. IEEE Sens. J. № 6. pp. 631-649. DOI: https://doi.org/10.1109/JSEN.2006.874493.

3. Bandyopadhyay S. and Cahay M. Proposal for a spintronic femto-Tesla magnetic field sensor, (2005) Physica E: Lowdimensional Systems and Nanostructures. № 1-2. pp. 98-103. DOI: https://doi.org/10.1016/j.physe.2004.10.012.

4. Phan M.H. and Peng H.X. (2008), Giant magnetoimpedance materials: Fundamentals and applications. Progress in Materials Science. Vol. 53. pp. 323-420. https://doi.org/10.1016/j.pmatsci.2007.05.003.

5. Zakharchenya B.P. and Korenev V.L. (2005), Integrating magnetism into semiconductor electronics. Physics-Uspekhi. № $\quad 48: 6 . \quad$ pp. 603-608. $\quad$ DOI: https://doi.org/ 10.3367/UFNr.0175.200506d.0629.

6. Titov A.N. and Dolgoshein A.V. (2000), Phase diagrams of the intercalate materials with a polar type of carriers localization. Physics Status Solidi. Vol.42, №3. pp. 425-427. 7. Seredyuk B.O. (2018), Analysis of the electrical, magnetic and structural properties of $\mathrm{A}_{3} \mathrm{~B}_{6}$ type layered semiconductor crystals intercalated with metals with reference to their military applications. Millitary-technical book. № 19. pp. 3943. DOI: https://doi.org/10.33577/2312-4458.19.2018.39-43.

8. Seredyuk B.O., Grygorchak I.I., Fomenko V.L. and Tovstyuk N.K. (2018), The Effect of the Fractal Guest Subsystem on the Structure, Heat Capacity and Impedance Response of InSe Crystals Intercalated with Nickel. Journal of nano- and electronic physics. vol. 10, №5. pp. 05009 (5 pp). DOI: https://doi.org/10.21272/jnep.10(5).05009.

9. Lukiyanets B.A., Matulka D.V. and Grygorchak I.I. (2018), Electronic spectrum of intercalated layered crystals: Model analysis. Journal of Nano- and Electronic Physics. № 10 (6), 06007. DOI: https://doi.org/10.21272/jnep.10(6).06007.

10. Politanskyi R.L., Politanskyi L.F., Grygorchak I.I. and A.D. Veriga (2018), Modeling of spin valves of magnetoresistive fast-acting memory. Journal of Nano- and Electronic Physics. № 10(6), 06027. DOI: https://doi.org/ 10.21272/jnep.10(6).06027.

\title{
АНАЛІЗ МАГНІТНИХ ВЛАСТИВОСТЕЙ НАПІВПРОВІДНИКОВИХ КРИСТАЛІВ ТИПУ А МЕТАЛЕВИМИ ДОМІШКАМИ $З$ ОГЛЯДУ НА ЇХ ВІЙСЬКОВЕ ЗАСТОСУВАННЯ
}

\author{
Б.О. Середюк
}

На магнітне поле Землі впливає наявність важкої військової бронетехніки, щуо створює додатковий магнітний момент. Це спотворення магнітного поля можна виявити за допомогою магніторезистивних структур. Ця стаття торкається основи можливості використання напівпровідникового матеріалу, такого як InSe, для високоточного вимірювання магнітного поля. Обговорюються властивості структур InSe щзодо електричних, магнітних та оптичних характеристик. Обговорюється ефект різкої анізотропії шаруватої структури InSе, яка полягає у сильному ковалентному зв'язку всередині шарів та слабкому зв'язку Ван-дер-Ваальса у прошарку міжшару, щюдо пояснення того, 
як змінюються електричні, магнітні та оптичні властивості. Розглянуто особливість просторової орієнтаціі матеріалу щодо напрямку магнітного поля. Досліджено вплив інтеркалящії InSe, GaSe різними концентраціями металевих домішок, таких як нікель та інші елементи 3d-групи заліза. Діаграми Боде для чистого InSе порівнюються 3 діаграмами NixInSe (для різних значень $x$ ). Також аналізується вплив різних температур від кімнатної до рідкого азоту на схему діаграм Боде. Проаналізовано ступінь зміни магнітних властивостей напівпровідникових кристалів типу $A_{3} B_{6}$ за наявності металевих домішок та їх кониентрації. Теоретична основа даної статті базується на загальновідомому твердженні, що структури шарів, такі як InSe або інші структури $A_{3} B_{6}$, можна розглядати як квазі-двовимірні. Отже, шари з міцним ковалентним зв'язком утворені атомами In-Se, тоді як прошарок заповнений слабким зв'язком Ван-дер-Ваальса. В рамках иієї моделі прочеси поперечно до шарів можна описати як збурення в порівнянні з прочесами в шарах. Це спричиняс сильну анізотропію властивостей иих структур. Військові застосування структур InSе, згаданих у цій роботі, полягають у тому, ще иі структури мають магніторезистивні властивості, $і$ вони виявились корисними для компонентів магнітних датчиків цивільного та військового призначення. Ця стаття також торкається основи того, як напівпровідникові кристали InSe, інтеркальовані $3 d$-елементами, можуть розширити функиіональність магнітних датчиків, призначених для виявлення важкої броні.

Ключові слова: напівпровідник, інтеркалячія, магнітне поле, наноструктури.

\title{
АНАЛИЗ МАГНИТНЫХ СВОЙСТВ ПОЛУПРОВОДНИКОВЫХ КРИСТАЛЛОВ ТИПА А МЕТАЛЛИЧЕСКИМИ ПРИМЕСЯМИ С ТОЧКИ ЗРЕНИЯ ИХ ВОЕННОГО ПРИМЕНЕНИЯ
}

\author{
Б.О. Середюк
}

На магнитное поле Земли влияет наличие тяжелой военной бронетехники, что создает дополнительный магнитный момент. Это искажение магнитного поля можно обнаружить с помощью магниторезистивных структур. Эта статья касается основы возможности использования полупроводникового материала, такого как InSe, для высокоточного измерения магнитного поля. Обсуждаются свойства структур InSe по электрических, магнитных и оптических характеристикам. Обсуждается эффект резкой анизотропии слоистой структуры InSe, которая заключается в сильной ковалентной связи внутри слоев и слабой связи Ван-дер-Ваальса в межслойной прослойке, с точки зрения того, как меняются электрические, магнитные и оптические свойства. Рассмотрены особенности пространственной ориентации материала относительно направления магнитного поля. Исследовано влияние интеркаляции InSe, GaSe различными концентрачиями металлических примесей, таких как никель и другие элементы $3 d$-группы железа. Диаграммы Боде для чистого InSe сравниваются с диаграммами Ni $i_{x}$ Se (для разных значений x). Также анализируется влияние различных температур от комнатной до жидкого азота на схему диаграмм Боде. Проанализирована степень изменения магнитных свойств полупроводниковых кристаллов типа $A_{3} B_{6}$ при наличии металлических примесей. Теоретическая основа данной статьи базируется на общеизвестном утверждении, что структуры слоев, такие как InSе или другие структуры $A_{3} B_{6}$, можно рассматривать как квази-двумерные. Итак, слои с крепкой ковалентной связью образованы атомами In-Se, тогда как прослойка заполнена слабой связью Ван-дерВаальса. В рамках этой модели процессы поперечно к слоям можно описать как возмущение по сравнению с процессами в слоях. Это приводит к сильной анизотропии свойств этих структур. Военное применение структур IпSе, упомянутых в этой работе, состоит в том, что эти структуры имеют магниторезистивные свойства, и они оказались полезными для компонентов магнитных датчиков гражданского и военного назначения. Эта статья также затрагивает основы того, как полупроводниковые кристаллы InSe, интеркалькированные $3 d$-элементами, могут расширить функииональность магнитных датчиков, предназначенных для выявления тяжелой брони.

Ключевые слова: полупроводник, интеркаляция, магнитное поле, наноструктуры. 